\title{
August Ahlqvist ja kansallinen teatteri
}

Omapohjainen teatterielämämme on niin nuorta; . että vielä vähän yli vuosisata sitten ei yksikään suomalainen mies taikka nainen yritellyt näyttämöllä muuten kuin tilapäisten seuranäytäntöjen osanottajana, niin kuin August Schauman hyvin elävissä muistelmissaan kertoo. ${ }^{1}$ Tosin esimerkiksi 1840-luvulla Helsingissä saattoi olla vilkkaitakin teatterikausia, mutta silloin oltiin täysin ulkomaalaisten kiertueiden varassa, vaikka oli jo olemassa omia teatteritaloja. Kiertueita oli esiintynyt aina 1700-luvulta lähtien. Ja olihan meillä hiukan omaakin teatteriperinnettä: yliopiston perustamisen aikoihin esitettiin ylioppilasnäytelmiä, vieläpä muuan suomenkielinenkin Grik Justanderin eli Juustin ruotsista suomentama komedia, joka kumminkin on jäljettömiin kadonnut.

Ymmärrettävästi haaveet omasta vakinaisesta esittävästä teatterista elivät ja alkoivat 1800-luvun kansallisten aatteiden viritessä yhä useammin pukeutua sanoiksi. Jotkut kirjoittajat tarkoittivat ruotsinkielisen teatterin aikaansaamista, mutta pian puhuttiin myös jo suomenkielisestä teatterista, varsin rohkeastikin. Ruotsiksi kirjoittavia kansallisen teatterin esitaistelijoita olivat Agathon Meurman, sitten Zachris Topelius, Fredrik Cygnaeus ja Emil Nervander. Suomenkielisiä vetoomuksia suomalaisen ja nimenomaan suomenkielisen teatterin puolesta esittivät jo melko varhaisessa vaiheessa Pietari Hannikainen Kanavassaan, originelli Jakob Lagervall samassa lehdessä ja sitten myöhemmin Kaarlo Bergbom, suomalaisen teatterin varsinainen luoja. Ehkä vähemmän tunnettu kuin edellä mainittujen lausumat on August Ahlqvistin osuus suomenkielisen teatterin hank-

1. Aug. Schauman, Kuudelta vuosikymmeneltä Suomessa I. Jyväskylä 1924, s... 231 . 
keissa. Suomalainen, kansallinen teatteri kuului kumminkin hyvin olennaisesti Ahlqvistin kulttuuriohjelmaan. Hän puhui sen puolesta monissa yhteyksissä hyvinkin voimakkaasti ja toimi eri tavoin myös käytännöllisesti oman suomenkielisen teatterin hyväksi.

Ahlqvistin taistelu — tätä sanaa voitaneen tässä yhteydessä kyllä käyttää — suomenkielisen teatterin aikaansaamiseksi perustui hänen selkeään kulttuurilliseen kokonaisnäkemykseensä. Koko hänen elämänsä päämääränä oli suomen kielen kehittäminen kulttuurikieleksi, ja se taas merkitsi kansallisen sivistyspohjan luomista. Tähän suureen päämäärään tähtäsi Ahlqvistin toiminta tiedemiehenä ja yliopiston opettajana, niin myös hänen runoilijantoimintansa, joka sekin oli vain - niin kuin Ahlqvist joskus näennäisen vaatimattomasti sanoi - "kielellinen koe", samoin hänen työnsä runon teoreetikkona. Ja siihen ennen kaikkea tähtäsi hänen toimintansa kielenkäytön ja kirjallisuuden arvostelijana, vieläpä niin kiinteästi, että häneltä kielen muotorakenteen vakiinnuttamista vaatiessaan, ankarana oikeakielisyysmiehenä, jäi kielen taiteellinen, yksilöllinen kehittäminen ikään kuin näkökentän ulkopuolelle. Tästä paljolta johtui hänen Kivenkritiikkiensä sokea yksipuolisuus ja kohtuuttomuus. Juuri äidinkielen ja suomalaisen sivistyksen kehittämisen pohjalta hän lähti vaatimaan myös suomalaista, suomenkielistä teatteria.

Ahlqvistin kanta teatterikysymyksestä, hänen perusteensa, käy hyvin selvästi ilmi eräistä hänen Suomettareen laatimistaan kirjoituksista. Arvostellessaan keväällä 1859 ylioppilaiden Helsingissä toimeen panemia Putronius-näytäntöjä - Pietari Hannikaisen Holbergin Erasmus Montanus -näytelmän mukaelman Anttonius Putroniuksen esityksiä - Ahlqvist kirjoittaa:

"Näinä päivinä on täällä vietetty juhlaa, joka on muistettava Suomen kansan ja kielen sivistyksen muisto-kirjoissa. Ylioppilaiset ovat nim. täkäläisessä teateri-huoneessa sitten toisen pääsiäis-päivän antaneet kometia-näytelmää Putroniusta, joka on kiitettävän kirjoittajamme P. Hannikaisen suomentama Tanskan kielisestä, Holberg'in tekemästä näytelmästä: Erasmus Montanus. Iloisella ja liikutetulla mielellä on jokainen Suomalaisuuden ystävä seuranrut tätä edesottoa, sitä iloisemmalla kuin tämän näytelmän antaminen teaterillisessakin katsannossa onnistui paljoa paremmin kuin äkkinäisiltä, ensi kerran teaterin laudoille astuvilta näytelijöiltä uskalsi toivoa. 
Ollessamme tässä näyttelössä heräsi meissä monta ajatusta, koskeva Suomen kielen asiata. Niin ajattelimme esim. että teaterin avutta ei ole yksikään nuorị kansa saanut kieltänsä oikein kelvolliseksi sivistyksen asioita ajamaan; Wenäläiset, Madjaarit, Wlämiläiset j.m.m. ovat kauan sitten hankkineet itselleen kelvolliset kansalliset teaterit ja hyvän siihen kuuluvan kirjallisuuden." 2

Seuraavana vuonna Ahlqvist jälleen palaa Suomettaressa -sarjassaan "Kirjoituksia Kilpiselle" - teatterin merkitykseen kielen kehittäjänä. Aiheen antaa tällä kertaa se, että Fredrik Cygnaeus oli "Taide-yhteyden" kokouksessa tehnyt ehdotuksen taideakatemian perustamisesta Suomeen. Ahlqvist pitää ajatusta kerrassan mahdottomana, koska Suomen köyhällä kansalla ei ole sellaiseen varaa. "Englannin ja Amerikan miljoni-herroille", Ahlqvist vähän ivallisesti sanoo, : "sitä vastaan sopii, levähtäessään ponnistavista ajatuksista pummulin, guanon j.m. kaupassa, uhrata joku ropo saaliistansa taidottarenkin hyväksi, ja ilahuttaa kopeuttansa näkemällä taiteen tuotteita hoviensa saliloissa." Sen sijaan "Suomen kansalla, joka vielä taistelee ruumiillisen puutteen kanssa, ei liene varaa uhrata 'elämän kaunistukseksi' ennenkuin petäjäistä, virsuja ja suksia ei löydy muualla kuin oppi-laitosten säily-huoneissa näytteeksi, 'kuinka meidän raa'at ja köyhät esi-isämme elivät'". Tisäksi Ahlqvist katsoo, ettei kuvaamataiteilla ole ollut juuri vaikutusta itse kansan sivistämisessä. Hän viittaa $\mathrm{mm}$. Italiaan, jossa kautta aikojen taiteet ovat kukoistaneet, mutta kansa on pysynyt perin sivistymättömänä. Tätä kuvaamataiteista varsin kirpeästi ilmaistua käsitystä vastaan asetettuna korostuu aivan erityisesti Ahlqvistin positiivinen käsitys teatterista koko kansan sivistäjänä: 'Näyttely-taiteen eli teaterin vaikutus sitä vastaan on välittömämpi ja väkevämpi sentähden, että sen niinkuin kaiken runouden väli-kappaleena on kieli, jotta sen tuotteita ymmärtääkseen ei tarvita paljon muuta kuin ymmärtää se kieli, jolla näyttely tapahtuu. Ja tämän väli-kappaleensa, kielen, päälle vaikuttaa teateri-näyttely arvaamattoman paljon sen sivistämiseksi, korottamiseksi ja keventämiseksi. Sentähden ei se olekaan yhtä kaikki, millä kielellä näyttely tapahtuu, ja kaikissa sivistyneissä kansoissa pidetäänkin äitin-kielen hoidosta teaterilla hellin huoli."”

\footnotetext{
2 Putronius Helsingissä. Suometar 1859, n:o 17.

${ }^{3}$ Kirjoituksia Kilpiselle 8. Suometar 1860, n:o 14.
} 
Ollessaan 1861-62 opintomatkalla Tanskassa, Saksassa ja Böömissä Ahlqvist lähetti matkakirjeitä Polénin Mehiläiseen. Niissä hän koskettelee mm. taiteita. Eräässä Pragista lähetetyssä kirjeessä hän jälleen korostaa teatterin erikoislaatuista merkitystä kielen kulttuurillisena kehittäjänä. Hän tähdentää, mitenkä monet Euroopan suuret kansat, kuten venäläiset ja unkarilaiset, ovat "suurilla ponnistuksilla hankkineet itsellensä teaterin omilla kielillänsä, sillä oikein he ovat tunteneet, että teateri voipi olla väkevä kielen ja mielen sivistyskeino"."

Lausumassa kiinnostaa erityisesti Ahlqvistin rinnastus kieli ja mieli. Hän oli varhaisesta nuoruudesta - oppi-isänsä Snellmanin aatteiden innokkaảna omaksujana - kiivas fennomaani. Yhden mielen ja yhden kielen vaatimusta hän julisti jo nuorena ylioppilaana. ${ }^{5}$ Mahtavana, mieliä sytyttävänä se ilmenee hänen 1860 julkaisemassaan "Suomen valta" -runossa. Ja vielä Porthanin patsaan paljastustilaisuuteen 1864 kirjoittamassaan runossa Ahlqvist julistaa yhden mielen ja yhden kielen ohjelmaa. Mutta pian tämän jälkeen alkoi ilmetä Ahlqvistin tunnettu antagonismi jyrkkiä suomenkielisiä kohtaan. Palattuaan pitkältä tutkimusmatkaltaan Venäjältä ja Siperiasta v. 1859 Ahlqvist kumminkin vielä veti täysin yhtä köyttä muiden suomalaisuusmiesten kanssa. Ja kuvaavaa on, että Yrjö Koskinen, sittemmin Ahlqvistin pahin kiistakumppani, oli Venäjän-matkan viime vuosina toivotellut häntä tulemaan takaisin antamaan suomalaisuustyölle uutta puhtia. Ahlqvist tekikin erityisesti noin paluunsa jälkeisinä vuosina monin tavoin aatteellista, julistavaa ja myös käytännöllistä työtä suomalaisuuden hyväksi. Suomettaren toimittamisessakin hän oli jälleen kiinteästi mukana ja hoiteli lehdessä sekä oikeakielisyyspalstoja että kulttuuripoliittista kirjoittelua kiivaassa suomalaiskansallisessa hengessä. Tähän työhön kuului osana juuri hänen taistelunsa suomalaisen teatterin puolesta.

Oman suomenkielisen teatterin perustamisajatuksen ensimmäiset esittäjät Hannikainen ja Lagervall - niin suomalaisia kuin he mieleltään olivatkin — näyttävät katsoneen asiaa suurelta osin talou-

* Mehiläinen, 1862, n: o 11.

5 Ks. esim. Ahlqvistin puhetta "Muuan sana siksi kutsutusta Sävolaĩs-Kärjalaisesta osakkeesta" 14.5. 1846. Savo-karj: osakunnan sanomalehtikirjoituksia 1835-1851. HYK. 
dellisena kysymyksenä ${ }^{6}$, samoin Meurman, joka muuten olikin oman myöhemmän tunnustuksensa mukaan asiasta aivan ensimmäisenä v. 1844 kirjoittaessaan tarkoittanutkin ruotsinkielistä teatteria. ${ }^{\top}$ Tunnettu on intomielisen Lagervallin laușuma siitä, mitenkä, "suomalaisen kuvaiston" [teatterin] perustaja "haprisi rahoja sääveliisä. joita nyt muukalaiset kokoiloot ja mänöövät häntä suorana kuịa kissat saalineen".8

Ahlqvistin lähtökohta oli puhtaasti aatteellinen ja kulttuurillinen. Hän näki teatterin, niin kuin edellisistä lausụmista on ilmennyt, tärkeänä kielen kehittäjänä ja suomalaisuuden.. voimakkaana-edistäjänä. Kansallisromantiikan tuulien puhallellessa ei kielikysymys alkujaan ollut hallitsevassa asemassa. Innostus kaikkeen kansalliseen oli yleinen yli kielirajojen. Kansallisen teatterin asiakin oli yhteinen; "eikä"senvuoksi ajateltukaan muuta kuin että saavutettu voittokin olisi yhteinen", kuten Aspelin-Haapkylä sanoo teatterihistoriassaan.9 Näin ihanteellisesti oli laita vielä 1850-luvulla. Mutta jo vuosikymmenen taitteessa ja varsinkin sitten 1860-luvulla, jolloin ruotsalaisuuden liike varsinaisesti syntyi ja puoluejako muodostui, asiat saivat toisen käänteen.

Kun vuonna 1851 maaliskuun neljäntenäkolmatta esitettiin. ensị kerran 'Topeliuksen ja Paciuksen luoma ooppela Kaarle kuninkaan metsästys, teaatteri-innostus oli valtava. Ja esityksen jälkeen vietetyssä Seurahuoneen juhlassa merkittiin huomattava summa uutta "kiviteatteria" varten - vanha puinen teatterirakennus oli : putut:teelliseria jo kauan herättänyt tyytymättömyyttä. Kaikessa - tuntui lämmin isänmaallinen intomieli. Ja yhteenkuuluvuuden tunnetta: varmaan vahvisti vielä edellisvuonna annettu ankara sensuuriasetus; jolla pyrittiin kuristamaan suomen kieli. Mutta kun uusi teatteri sitten vihdoin vuosikymmenen vaihteessa alkoi valmistua, asenteet.:

' Ilmari Kohtamäki, Pietari Hannikaisen 'Kanava'. Turku 1959, s. 90-91.

"Helsingfors Tidningar 1844, n:o 19. - Agathon Meurman, Muistelmia. Ffelsinki 1909, s. 139. - Paavo Virkkunen, Agathon Meurman I. Helsinki 1935; s. 288-291. - Meurman suhtautui vielä puolitoista vuosikymmentä myöhemminkin hyvin epäilevästi suomenkielisen teatterin malıdollisuuksiin...Ks. hänen kirjoi tustaan Åbo Tidningarissa 23.4. 1858.

8 Alunperin Lagervallin kirjeessä Elias Lönnrotille 1. 3. 1847. SKS.

- Eliel Aspelin-Haapkylü, Suomalaisen teatterin historia I. Helsinki 1906, s. 12. 
olivat toiset. Teatterista näytti tulevan — ja tulikin - täysin ruotsinkielinen. Syystä Ahlqvist arvostellessaan mainittua Putronius-esitystä sai aiheen lausua kiivaita sanoja suomalaisuuden puolesta.

"Suomen kansan varoilla", Ahlqvist kirjoittaa, "raketaan nyt kanssa kallista teateria, jonka vuotinen ylöspito tulee myös menemään samoista varoista. Onkohan tämän edesoton johtokunta ensinkään arvellut jollain tavalla Suomen kansalle palkita tätä anteliaisuutta? Johtokunnalla ja muilla sitä epäilevillä on nyt Helsingin kaupungissa ollut jo kaksikin kertaa tilaisuus nähdä, että ja kuinka Suomen kieli on soveljas sivistyksen välikappale näytännöllisessäkin katsannossa. Ei suinkaan siis olisi liikanaista että saman uuden teaterin rakennuttajat jo ajoissa päättäisi hankkia uutta suomenkielistä näytännöllistä kirjallisuutta ja edes pari eli kolme kertaa vuodessa toimittaa suomalaisia näyttelöjä mainitussa teaterissa, sen valmistuttua; sillä jos tätä ei tehdä, on tähän rakennukseen pantu raha upotettu mereen eli korkeammakseen uhrattu vaan Helsingin herrasväkien huvitukseksi, joka ei mahtane olla antajien tarkoitus. Ja ruotsinkielistä teateria ei Suomessa tarvitse kehoittaa ýhteisillä varoilla; Ruotsin kieli on ollut sivistyksen välikappale Suomessa, ja on Suomelta myös ottanut kuninkaallisen palkan tästä vaivastansa: tuotteet Runeberg'in, Snellman'in, Topeliuksen ja lukemattomien muiden Suomen miesten hengellisestä työstä, jotka tuotteet eivät voi olla muuta kuin Ruotsin kielen ja kansan omaa, ja joten Suomi Ruotsin hyväteosta on kuitti." 10

Lausuman loppu on kiintoisa sen vuoksi, että Ahlqvist tässä katsoo kaiken ruotsalaiselta taholta saadun kulttuurivelan kuitatuksi, toisin kuin sitten 1870-luvulla, jolloin hän joutui kiivaseen polemiikkiin Yrjö Koskisen kanssa juuri kulttuuriveloista. Yrjö Koskinen edusti sitä kantaa, ettei mitään kiitollisuudenvelkoja ole yleensäkään kansojen välillä olemassa; Ahlqvist puolestaan tuolloin korosti, että meillä oli saamastamme kulttuurista kiitollisuudenvelka Ruotsia kohtaan. Ahlqvistin käsitys siis muuttui vuosien mennen. Siihen oli monia syitä, kuten olen toisessa yhteydessä voinut osoittaa. ${ }^{11}$

Mainitussa kirjoituksessaan Ahlqvist kumminkin vielä esiintyi mitä kiihkeimpänä fennomaanina. Vaikka hänellä oli aihetta kohdistaa ankaraa kritiikkiä ruotsalaisuuden pyrkimyksiä kohtaan, hän

10 Suometar 1859, n:o 17.

11 Ilmari Kohtamäki, Ankara puutarhuri. Vammala 1956, s. 316-325. 
ei näyttänyt menettäneen sentään kaikkea toivoaan siitä, että uudessa teatterissa suomen kielikin saisi sijan ja että suomenkielisellä teatterilla kaikesta huolimatta olisi tulevaisuutensa: "Uuden teaterin valmistuttua toivomme siis useasti ja aina useammin saavamme nähdä ja kuulla Suomen kieltä teaterilla, ja kuin noin viiskymmentä vuotta eteenpäin omituinen, suomenkielinen teateri on jo kasvanut voimalliseksi kansallis-laitokseksi, kuin iloisella mielellä luodaan muisti takaisin Suomen teaterin surkeaan alkuun, niin totta silloin kysytään sitäkin: keitä olivat ne miehet, jotka tekivät alun asiassa?" Ahlqvistin profetia tuntuu silloisia oloja ajatellen rohkealta. Se sai kumminkin täyttymyksensä. Jo ennen kuin oli kulunut puoli vuosisataa, meillä todella oli oma suomenkielinen teatteri, ja se oli - kuten Ahlqvist ennusti - voimakas kansallinen sivistyslaitos. Vuonna 1860 Ahlqvist Suomettaressa Kilpisen-kirjeessään jälleen taittaa peistä sen vuoksi, että Helsingin uudessa teatterissa ei suomen kieli kumminkaan näytä saavan sijaa. Kirjoittajan kanta ei enää ole niin toiveikas kuin edellisvuonna: "Hyvin arvaat siis millä silmällä jokainen Suomen kielen rakastaja on katsonut muutamain sanomain menetystä kysymyksessä Helsingin uudesta teaterista. Tälle laitokselle on hankittu etuja ja apuja hallitukselta, tälle tahdotaan antaa $\mathrm{k}$ a $\mathrm{n}$ s a $1 \mathrm{l}$ is e $\mathrm{n}$ teaterin nimi, tästä luullaan heruvan uuden elämän ja sivistyksen yli koko maan, ja kuitenkaan ei sen siunauksista puhuessaan maan omalle kielelle anneta sen enempää kunniata kuin että tämän kielen vasta-maailmassa (kuinka monen vuosi-sadan perästä, se jätetään määräämättä) luullaan ehkä saavan siinä jonkun sian." 12 Ahlqvist katsoo, että jo "paljas 1 u p a u s teateri-valtikkain puolesta" suomen kieltä kohtaan olisi ollut parempi "kuin tyhjä liehakoiminen ja asian kierteleminen".

Samassa kirjoituksessa Ahlqvist puhuu teatterikoulusta, jota jo tuolloin puuhattiin ja jota varten ylioppilaat olivat antaneet pohjarahastoksi suurimman osan näytäntötuloistaan, 500 r'uplaa. Ahlqvist vaatii, että koulussa olisi annettava arvo suomen kielelle, oppilaiden olisi ymmärrettävä suomea ja sitä olisi laitoksessa ahkerasti opetettava. Toisin kuitenkin kävi: kun koulu vihdoin viimein vuonna 1866 avattiin, vain pari kolme otetuista oppilaista osasi suomea. ${ }^{13}$

\footnotetext{
12 Suometar 1860, n:o 14.

${ }^{13}$ Aspelin-Haapkylä, mt. I, s. 26.
} 
Vielä Ahlqvist mainitussa Kilpisen-kirjeessään tähdentää teatteritoiminnan laajentamista ympäri Suomen: "Ja yli koko maan pitäisi suomalaisuuden ystävien matkaan-saattaa suomen-kielisiä teateriharjoituksia. Tiettävästi on tämmöisiä näyttelyitä jo ollut monessa maamme paikassa niinkuin: Oulussa, Kuopiossa, Sortavalassa, Lappeenrannassa, Wiipurissa j.m. Joka paikassa niistä on ollut elähyttävä harjoitus sivistyneelle nuorisolle Suomen kielessä." Lopuksi Ahlqvist.vielä kehottaa Kilpistä panemaan "kaikki kaunottaret ja kaikki Lemminkäiset Jyväskylässä liikkeelle suomen-kielistä seuranäyttelyä hankkimaan".

Euroopan-matkallaan Ahlqvist tuli kokemaan Böömissä kielitaistelun maan tšekinkielisen pääväestön ja saksaa puhuvien kesken. Taistelu ilmeni mm. maan teatterioloissa ja oli juuri johtamassa siihen, että parhaillaan puuhattiin Pragissa omaa "Pyömin kielistä" teatteria. Olosuhteet olivat rinnastettavissa omiimme. Ja Ahlqvist sai virikkeitä kansallisille kielipoliittisille käsityksilleen ja pyrkimyksilleèn. ${ }^{14}$

Monissa eri yhteyksissä Ahlqvist näin puhui suomenkielisen teatterin puolesta, jo siis 1850-luvulta lähtien. Mutta vielä vuonna 1865 hänen oli todettava: "Vaan teateria ei meidän kielellä kumminkaan ole; ei hatarinkaan lato ole vielä pyhitetty Talian palvelukselle, ei repaleisintakaan mustalaisjoukkoa löydy, joka Suomen sanoilla kuvattëlēisi kansalle." ${ }^{15}$ Mutta sen sijaan, että Ahlqvist aikaisemmin oli pitänyt suomen kieltä kyllin sivistyneenä myös näyttämön kieleksi ${ }^{16}$, hän nyt puhuu "kielen kurjasta tilasta" ja katsoo että "'kielen pitää ensin valmistua kirjailijoiden ja runoniekkojen kamariloissa ja käyttämättömissä teoksissa ennenkuin se pääsee - - näyttelytaiteen käytettäväksi". ${ }^{17}$ Tämä on kieltämättä ristiriitaista. Osaltaan asiaa selittänee se, että Ahlqvist esitti tämän lausumansa ryhtyessään arvostelemaan Kiven Kullervoa, jonka hän perin pohjin teilasi. Kiven kieli ärsytti häntä ja kaiken kaikkiaan hän katsoi Kiveltä puuttuneen 'kypsyyttä, sivistystä ja muotoaistia". Kivenkin suhteen muuten Ahlqvistin kanta oli muuttunut. Olihan hän vielä 1860 ollut myöntämässä Kivelle palkintoa Kullervon ensimmäisestä

\footnotetext{
14 Mehiläinen 1862, n:0 11.

15 Suometar 1865, n: 018.

16 Suometar 1859, n:o $17 ; 1860, \mathrm{n}: 014$.

17 Suometar 1865, n:o 18 .
} 
laitoksesta ja jälleen seuraavana vuonna palkitsemassa hänen toista kalevalaisaiheista, sittemmin kadonnutta Aino-näytelmäänsä.

Kuitenkin on huomattava, että Ahlqvistin nyt 1860-luvun puolivälissä esittämä kritiikki ei kohdistunut ainoastaan Kiveen, sillä samassa yhteydessä - laajassa kirjoitussarjassa, jossa hän käsitteli Näytelmistön kolmatta osaa - hän ankarasti arvosteli mm. sitä, että oli rohjettu ryhtyä kääntämään suomeksi Shakespearea. Mainitussà Näytelmistön osassa oli nimittäin ilmestynyt myös ensimmäinen var. sinainen Shakespearen suomennoksemme, Kaarlo Slöörin kääntämä Macbeth. Ahlqvistin mielestä kieli ei ollut vielä kypsä tällaiseen voì: mainkoetukseen. Sanasto oli kehittymätöntä ja Kieletär liikkui 'kömpelösti ja hoiperrellen uudemmissa runopuvuissa". Kummïnkin Ahlqvist itsekin oli aikaisemmin kääntänyt eräitä näytelmiä suomeksi, mm. Schilleriä. Hyökkäyilyn taustana onkin ehkä huomattava myös se seikka, että Ahlqvistin: suhteet nuorfennomaaneihin alkoivat juuri näihin aikoihin kärjistyä.. Samalta vuodelta kuin mainittu kirjoitussarja on myös hänen kirpeä, paljon huomiota ja närkästystäkin herättänyt runonsa "Valtiollista", jossa ilmenevät hänen sympatiansa Ruotsiin kulttuurimme välittäjänä ja myös ruotsin kieltä kohtaan. Hyvältä osin lausuma saanee selityksensä Ahlqvistin luonteén affekti: suudesta ja hänen mielensä ärtyneisyydestä.

Kullervon arvostelussaan Ahlqvist muuten; kuten eräissä muissa: kin 'yhteyksissä, esitti myös teoreettisia mielipiteitään draamasta, erityisesti tragediasta: Draamankäsityksessään hän,: $\mathrm{mm}_{*}$ korostaes: saan perinteellis-klassisen murhenäytelmän tiukkaa' säännönmukai: suutta, osoittautuu varsin vanhoilliseksi. Paljon modernimpaa: kantaa edustivat jo esim. Fredrik Cygnaeus ja Kaarlo Bergbom. Esittäessään ajatuksiaan murhenäytelmän "puennosta" eli muodosta, joksi sopii ainoastaan "värsy", siis runoasu, Ahlqvist viittaa erääseen nimeltä mainitsemattomaan "kaunotieteen harjoittajaan", josta hän sanoo erityisestí pitävänsä. Tämän Ahlqvistin kiintoisan esteettisen oppi-isän tutkimus paljastaa saksalaiseksi kirjailijaksi ja poetiikan tutkijaksi Rudolph Gottschalliksi (1823-1909). Gottschallin poetiikkaan juuri näyttääkin perustuvan Ahlqvistin draamankäsitys, niin kuin liänen esteettiset mielipiteensä yleensä. ${ }^{18}$

1в Kohtamäki, Ankara puutarhuri, s. 200-203; 209-216. 
Vuonna 1862 kirjoittamassaan matkakirjeessä Ahlqvist puhuessaan Böömin teatterioloista lausuu kursailemattomaan tyyliinsä käsityksensä myös ajan näytelmäkirjallisuudesta, purevan kyynisesti erityisesti oopperasta: 'Nykyinen näytelmä-kirjallisuus on koko Euroopassa rappiolla. Eikä se olekaan kumma. Thalian käveltävän sillan on valloittanut opera, jonka sankarit tavallisesti ovat sitä laatua, jota Saksaksi kutsutaan 'Lump' eli Suomeksi rentale (esim. 'Stradella" ja 'Propheeta' ja monta muuta), ja näiden rentaleiden rentaleiset tapaukset ovat toiset rentaleet tehneet operan-pohjallisiksi, joille soitanto-mies sitten kutoo soitannon kaunistuksen." Alaviitteessä Ahlqvist lisää: "Don Juanissakin ja Figaron häissä on aine hyvin nuljakkata, vaan niiden ihana soitanto lahjoo kumminkin kuulijan, niin että hän unhottaa aineen rentaleisuuden." Kirjoittaja jatkaa: "Operan kanssa on tanssi karkoittanut Thalian templistänsä, niin että meidän-aikuiset ihmiset käyvät teaterissa enemmän ihmettelemässä laulajattarien huhuilemista ja tanssi-naisten alastomia pohkeita kuin ylentymässä siitä korkeasta nautinnosta, jonka Sophokleen, Shakespearen ja Schiller'in katsojat tunsivat." ${ }^{19}$

Ahlqvist katsoi siis teatterin ennen kaikkea ilmentävän sitä kauneuden muotoa, joka kuuluu ylevyyden kategoriaan. Esteettis-kasvatuksellisessa mielessä sen merkitys taasen oli tärkeä sen vuoksi, että se oli taiteen muodoista helpoimmin omaksuttavissa.

Vaikka ylevä draama oli näytelmän lajeista se, jota Ahlqvist ennen kaikkea arvosti, hän saattoi kuitenkin osoittaa myötämielisyyttä komediaakin kohtaan ja arvostella hyvinkin kiittävästi omia vaatimattomia yritelmiämme. Aivan erityisen arvon hän antoi Pietari Hannikaisen näytelmäkirjallisille tuotteille, joista hän v. 1860 sanoi, että "Hannikaisen teoksia ei tarvitsisi rikkainkaan kirjallisuus halveksia". ${ }^{20}$ Hyvin samaan suuntaan muuten oli käynyt J. V. Snellmanin mielipide Hannikaisen Silmänkääntäjästä. Varsin ylistävässä. arvostelussaan Litteraturbladissa hän sanoi mm., että Hannikaisen kappaleen "voi asettaa minkä samanlaatuisen vieraskielisen tuotteen rinnalle tahansa tarvitsematta pelätä sen joutuvan huonommaksi". ${ }^{21}$ Yleensä aikalaiset arvostelivat hyvin myönteisesti Silmänkääntäjää

19 Mehiläinen 1862, $\mathrm{n}$ : 011.

${ }^{20}$ Suometar 1860, n:o 14 .

${ }^{21}$ Litteraturblad 1848, n: 012. 
- poikkeuksena kriittisen Fredrik Cygnaeuksen ja Oskar Toppeliuksen lausunnot. Myöhemminkin se on vielä saanut tunnustusta. ${ }^{22}$ Epäilemättä Hannikaisen tuotteet ensimmäisinä esityskelpoisina suomenkielisinä näytelminä veivät huomattavasti suomalaisen teatterin asiaa eteenpäin. Yllättävältä kumminkin tuntuu, että Ahlqvist vielä vuonna 1882 Kotikielen Seuran kokouksessa esitellessään ihastuneena Minna Canthin Murtovarkautta saattoi katsoa, että suomalaisista alkuperäiskomedioista vain Hannikaisen Silmänkääntäjää voi verrata siihen. ${ }^{23}$ Eihän allkuperäiskomedioita vieläkään monia ollut. Mutta oli toki tuolloin kulunut jo kahdeksantoista vuotta Kiven Nummisuutarien ilmestymisestä ja se oli saanut menestyksellisen esityksensä teatterissakin! Mutta Ahlqvisthan ei Kiveä eikä Kiven huumoria ymmärtänyt, ja sitä paitsi suhtautumisen taustana oli ilmeisesti henkilökohtaisiakin vaikutteità.

Ahlqvistin käytännöllinen toiminta suomenkielisen teatterin hyväksi alkoi hänen palattuaan pitkältä tutkimusmatkaltaan. Kun ylioppilaat v. 1859 esittivät mainittuja Putronius-näytäntöjään, Ahlqvist oli sikäli osallisena asiassa, että hän yhdessä Oskar Toppèliuksen kanssa muokkasi Hannikaisen mukaelman teatteriin sopivaksi. Ja näytelmä sai suopean vastaanoton.

Vuonna 1860, jolloin Ahlqvist jälleen oli mukana Suomettaren toimituksessa, hän julkaisi tässä lehdessä kaksi näytelmäsuomennosta, nimittäin saksalaisen R. Benedixin kaksinäytöksisen Rïta-asian ja Molièren alkuperäisteoksen mukaan sommitellun yksinäytöksisen "ilveillyn" Väkinäinen naiminen. Käännöstyötään Ahlqvist perusteli nimenomaan sillä, että täten oli tarkoitus edistää suomenkielisten näytelmien aikaansaamista, ja sen vuoksi oli "Suometar päättänyt suomennellà ja mukaella pienempiä näytelmiä muista kielistä, semmoisia, jotka kokonsa, aineensa ja sisällyksensä puolesta näyttävät sopivilta näyteltää seura-teateriloilta". ${ }^{24}$ Molemmat näytelmät ilmestyivät sitten vielä samana vuonna erillisinä kirjasina. Myöhemmin niistä otettiin uusia painoksia, joten niitä ilmeisesti on eri seuranäyttämöillä esitetty. Rïta-asian esittivät ylioppilaat Helsingissä jo ke-

\footnotetext{
${ }^{22}$ Kohtamäki, Pietari Hannikaisen 'Kanava', s. 52-54.

${ }^{23}$ Kotikielen Seuran pöytäkirja 4. 3. 1882.

${ }^{24}$ Suometar 1860, n:o 14.
} 
väällä 1860 useaan otteeseen, ja pariinkin kertaan se eri aikoinậääsi sittemmin myös Suomalaisen teatterin ohjelmistoon. ${ }^{25}$ Vaateliaampi Ahlqvistin suomennostyö oli Schillerin Kabale und Liebe -näytelmäṇ käännös Kavaluus ja rakkaus. Suomennos on vuodelta 1863. Näytelmä esitettiin Bergbomin teatterissa ainakin neljään eri otteeseen. ${ }^{26}$

Ahlqvistin kiinnostusta käytännölliseen teatteritoimintaan — nimenomaan suomalaisten kappaleiden saamiseen näyttämölle - osoittaa: myös muuan hänen innokas aloitteensa. Ollessaan Keski-Euroo: passa tutkimusmatkalla Ahlqvist näki syystalvella 1861 Berliinin Kuninkaallisessa teatterissa näytelmänä. — tai ehkä paremminkin kuvaelmana - Schillerin kuuluisan runoelman "Laulu kellosta".. Ahlqvist oli suomentanut sen pari vuotta aikaisemmin yliopistossa vietettyyn Schillerin syntymän satavuotisjuhlaan. Taidokas suomennos oli herättänyt suurta huomiota - sitä pidettiin suorastaan suomalaisen runokielen merkittävänä kypsyydennäytteenä. On ymmärrettävää; että se nyt näyttämölle asetettuna kiinnosti kääntäjää erityisesti. Ja hän sai ajatuksen, että se voitaisiin amatöörivoimin esittää myös Helsingissä. Ahlqvist kirjoitti asiasta hyvin innostuneena Oskar Toppeliukselle. ${ }^{27}$ "Huolimatta siitä", Ahlqvist sanoo kir"jeessään, " "että kappaletta varmaankaan ei ole ajateltu tällaista esitystä varten, se tuntui erinomaisen sopivalta ylioppilasnäytelmäksi; kysynkin 'Sinulta: eikö 'Das Lied von der Glocke' sopisi suomenkielisenä näytelmäseuran seuraavaan ohjelmistoon? Kappale on help:po esittää, myös naiset voivat olla mukana, sillä kellon valannan aikana: esitettävät mietelmät tulevat monen henkilön osalle; niin että kukin joutuu lausumaan aivan vähän. Mèstarilla on eniten sanottavaa..".."

Sen jälkeen Ahlqvist kuvailee Berliinin teatterissa näkemäänsä näyttämöllepanoa: "Näyttämönä on holvattu valimohuone, taka-alalla suuri sulatusuuni. Etualalla on maahan tehty syvennys, jossa on. kellonmuotti. Mestari ja oppipojat ovat yksinkertaisesti pukeutuneita, nahkaesiliinat vyöllä; kisällit hoitelevat uunia, käväisevät muot. tikuopassa ym. Kun mestari sitten on selittänyt, että metalli on valmis valettavaksi, kisällit työntävät pitkällä rautatangolla (sillä

${ }^{25}$ [M. Weckström] Anteckningar rörande teatern i Finland (Materialsamling), Helsinki 1864, s. 26. - Aspelin-Haapkylä, mt. IV, s. 343.

${ }^{26}$ Aspelin-Haapkylä, mt. IV, s. 330.

${ }_{2 \pi}$ August Ahlqvistin kirje Oskar Toppeliukselle 8.11.1861. HYK (Sulo Haltsosen kopio). 
muuten ei voisi lähestyä tulenhehkuista uunia) pois tulpan, ja kuohuen virtaa nyt sula metallimassa muottiin. Mestarin palvelustytöt kulkevat ympäri hoidellen tarjoilua: Vuoropuhelu jatkuu keskeytymättä. Kun muotti on särjetty ja todetaan, että valu on onnistunut, kello hinataan kuopasta kattoon kiinnitetyn väkipyörän avulla. Nimi Concordia, jonka mestari huutaa, on kellon kupeessa. Sinä aikana, jolloin ensin mestari, sitten koko joukko yhdessä lausuu kaksi viimeistä säkeistöä, kuuluu vienoa, hiljaisia kellon läppäyksiä muistuttavaa musiikkia.

"Kappale on todella vaikuttava ja luulisin, että se suomeksi esitèttynä olisi taas kukonaskel kohti suomenkielistä näyttämöä. - Ainoa vaikeus lienee saada näyttelijät lausumaan sanat selvästi ja vuoropuhelu jatkumaan keskeytymättä. On myös kaiken aikaa luontevasti liikehdittävä. Mestarin äiti, vaimo ja tyttäret voivat pysytellä etualalla, koska heillä ei ole mitään varsinaista tehtävää itse valutyössä. Yhden mestarin tyttären ja erään kisällin välillä ilmenee hellä suhde."

Ahlqvist jättää sitten Toppeliuksen ja näytelmäyhdistyksen ratkaistavaksi, olisiko ehdotus toteutettavissa. Ja näkyykin Ahlqvistin heti seuraavan vuoden alussa Toppeliukselle lähettämästä kirjeestä ${ }^{28}$, että aloite on tavannut kyllä vastakaikua. Toppelius näyttää pyytäneen Ahlqvistilta runoelman dramatisointiselostetta, koskapa Ahlqvist on kääntynyt teatterinjohtaja Düringerin puoleen ja saanut häneltä haltuunsa "kuiskaajan-kappaleen". Hän lähettää nyt osajaon omaan käännölkseensä sovitettuna tarkkoine ohjeineen Helsinkiin. Näköjään Toppelius on myös tiedustellut runotekstiin sovituksessa tehtävistä muutoksista, minkä johdosta Ahlqvist saa aiheen huomauttaa: "Tekstin muutoksista, mihin näytät tuntevan halua, Düringer tähdensi minulle, niin kuin jo ennalta tiesinkin, että hän ei ollut muuttanut mitään, vaan seurannut sana sanalta Schillerin tekstiä." Ja sitten Ahlqvist jatkaa hänen itsetietoisuuttaan hyvin kuvaavạlla tavalla: "Myös minä panen sen ehdon käännökseni esittämiselle, èttei pilkkuakaan muuteta, en itserakkaudesta, vaan koska tiedän ettei Helsingissä ole ketään, joka voisi parantaa käännöstä, jonka olen

${ }^{28}$ August Ahlqvistin kirje O. Toppeliukselle 6. 1.1862. HYK (Sulo Haltsosen kopio). 
tehnyt niin huolellisesti. Sen käsittää hyvin jokainen, ken edes jossakin määrin ymmärtää Suomen kieltä."

Dekoraatioista Ahlqvist sanoo olleen suuren puuhan, ja berliiniläinen teatterinjohtaja oli vähintään kymmenen kertaa käynyt tutustumassa valimoon. Ahlqvist on hyvin tietoinen siitä, ettei Helsingissä ole mahdollisuutta saada esitystä yhtä täydelliseksi kuin hänen Berliinissä näkemänsä. Hän mainitsee sitten erään helsinkiläisen valimon, jossa Toppelius voisi oppia yhtä ja toista esitystä varten. Ja vielä kerran Ahlqvist tähdentää, että pääasia on luonteva liikehtiminen ja sopiva henkilöryhmittely, sekä varoittaa liiasta paatoksellisuudesta lausunnassa. Hiukan paradoksaalista muuten, että tämä suomen kielen ja suomenkielisen teatteriharrastuksen edistämiseen näin intomielisesti tähtäävä kirjeenvaihto käytiin ruotsiksi!

En ole voinut todeta, onko kuvaelma tullut esitetyksi. Ilmeisesti Ahlqvist on luottanut liikaa harrastelijaseuran mahdollisuuksiin juuri lavastuksellisessa mielessä. Hän on Berliinissä nähnyt hienon näyttämöllepanon, mutta ei ole ottanut huomioon, kuinka vähäiset mahdollișuudet silloisissa oloissa ja vielä amatöörivoimin oli edes tavoitella yhtä aidontuntuista lavastusta kuin Berliinissä. Niinpä esittäminen on saattanut tästä syystä jäädä.

Ahlqvistin teatterille tekemistä palveluksista voinee ohimennen huomauttaa vielä siitä, että Suomalaisen teatterin avajaisnäytännössä ja sitten myöhemminkin kuvaelmana esitetyn Runebergin "Pilven veikon" käännös oli hänen käsialaansa, tosin jo paljon varhaisemmalta ajalta. Mainita ansaitsee niin ikään, että Ahlqvist oli johtokunnan esimiehenä vuonna 1869 perustetussa Suomalaisessa Seurassa, joka pyrki ajamaan suomalaisuuden asiaa taiteen aloilla ja jonka toiminta - niin kuin Aspelin-Haapkylä sanoo — oli "johdanto kansalliseen teatteriin".29

Voidaan todeta, että August Ahlqvistin nimi hyvin merkittävällä tavalla liittyy myös kansallisen näyttämömme luomisvaiheisiin. Traagista vain on, ettei hän, vilpittömistä suomalaisuuspyrkimyksistään huolimatta, kyennyt draaman alalla enempää kuin muutenkaan näkemään Aleksis Kiven suuria ansioita.

ª Aspelin-Haapkylä, mt. I, s. 147, 149. 


\section{ILMari KoHTaMäKr: August Ahlqvist and the national theatre}

It is known that Pietari Hannikainen and Jakob Lagervall in the 1840s and somewhat earlier Agathon Meurman were among the first advocates of the Finnish theatre. The latter explained that he had the Swedish speaking theatre principally in mind. The part played by August Ahlqvist as a pioneer of the Finnish language theatre is less well known. In any case he was a particularly important and vigorous spokesman among those who supported the Finnish theatre and especially the Finnish language theatre

The first-mentioned supporters of the idea of a Finnish theatre, though they were Finnish extremists, considered the question mostly from a utilitarian point of view, as a financial matter. Ahlqvist's strarting point was purely idealistic and cultural. He saw the theathe more than anything as a cultural instrument for developing the language and as a powerful promoter of the Finnish cause. It was for this reason that the idea of creating a Finnish language theatre belonged essentially to his cultural programme. The great object of his life's work was to develop the Finnish language for cultural purposes. His activity as a scholar, university teacher, poet and poetical theorist was all directed to this purpose. But above all it was his work as a critic of language and literature, as the first important grammarian which fulfilled this aim. It was precisely his interest in developing the mother tongue and Finnish culture that led to his demand for a Finnish language theatre. He saw, and many times emphasized, that no nation had succeeded in making of its language an instrument for furthering eivilization, without a theatre.

On his return from a long journey to Russia and Siberia, Ahlqvist spent the late 1850 s and early $1860 \mathrm{~s}$ writing forcefully and many times in the newspapers "Suometar" and "Mehiläinen" in support of the idea of a Finnish language theatre. He also did practical work for the national theatre. He was active in his support of Finnish language productions by the student drama society and he translated into Finnish a number of plays which were subsequently also presented at Kaarlo Bergbom's Finnish theatre. Ahlqvist was also chairman of the board of the Finnish Society, founded in 1869. This society aimed at furthering Finnish language interests in artistic fields, and its activity, in the words of Eliel Aspelin-Haapkylä the Finnish theatre historian, constituted "an introduction to the National Theatre". 